\title{
The Differences Ability to Solve Problems from Learning Model Eliciting Activities (MEAs) with Direct Learning Seen from Gender
}

\author{
Juli Mania Sembiring $^{1^{*}} \quad$ Asmin $^{2} \quad$ Mangaratua Simanjorang $^{2}$ \\ 1.Graduate Program School in Mathematics Education, State University of Medan, \\ Jl.Williem Iskandar Psr.V Medan Estate, 20221, Sumatera Utara, Indonesia \\ 2.College Teacher State University of Medan, Jl. Williem Iskandar Psr.V Medan Estate, 20221, Sumatera Utara, \\ Indonesia
}

\begin{abstract}
This study aims to analyze : (1) differences in the ability to solve mathematical problem students who obtain learning Model Eliciting Activities (MEAs) with direct learning, (2) interactions between learning models (learning Model Eliciting Activities and Direct Learning) with the gender of students (male men and women) towards students' mathematical problem solving ability. The population in this study were all students of class VIII by taking a sample of two classes. The instrument used tests mathematical problem-solving ability. Data analysis was performed using two-way analysis of variance (AN AVA). The results empirically $\mathrm{n}$ indicate: (1) there is a difference ability solving mathematical problems students acquire learning Model Eliciting Activities (MEAs) to students who obtain direct learning, (2) there is no interaction between learning model (learning Model Eliciting Activities and Learning Direct) with the gender of students (male and female) to students' mathematical problem-solving ability.
\end{abstract}

Keywords: Model Eliciting Activities (MEAs), problem solving ability, Gender.

DOI: $10.7176 / \mathrm{JEP} / 10-30-02$

Publication date:October $31^{\text {st }} 2019$

\section{Introduction}

Education has become a very important thing, even the need for education is almost aligned with the basic needs. Similarly, technology is now very rapidly developing. If someone wants to be able to follow and even create new technology, then always have to study science. This is one of the roles of education, which is to equip students with a variety of knowledge that is needed for life. In education, a lot of knowledge has been explored to improve the quality of Human Resources (HR), one of which is mathematics.

Mathematics plays an important role in the development of science and technology, is universal that underlies the development of modern technology, requires the ability to think logically, systematically, critically, creatively, and innovatively. Therefore mathematics is very necessary for daily life.

One of the ability that students must have in learning mathematics is the ability to solve mathematical problems. This is in accordance with the five aspects of mathematical ability as formulated by the National Council of Teachers of Mathematics (NCTM) (2000: 7) including: " (1) mathematical communication ; (2) mathematical reasoning ( mathematical reasoning ); (3) mathematical problem solving ; (4) mathematical connections ; and (5) the mathematical representation ( mathematical representation) ".

In fact, students' mathematical problem-solving ability are still low. It is appropriate from a math test results that the author did in junior IT Nurul Fadhilah Deliserdang on Al-Qowiyyu VIII class by the number of students 25 people. Based on the students' answers on the first indicator of problem-solving ability, that is to understand the problem, there were 15 students $(60 \%)$ were able to write what they know and asked the question and 10 students $(40 \%)$ have not been able to understand the problems that derive right next to the indicator the second is planning problem solving, there are 7 students $(28 \%)$ who are able to plan problem solving using numbers and fractions on the questions that get it and 18 students (72\%) there are still errors in determining the concept or formula, the third indicator is to solve the problem according to the plan there were 5 students $(20 \%)$ able to solve correctly according to the plan and the remaining 20 students $(80 \%)$ did not answer the problem correctly and did not match the problem planning.

In line with the results of observations and problem solving ability tests conducted by Jainuri \& Riyadi (2017: 52) states "in students at Merangin 12 Middle School it is known that more than 50\% of students have not been able to understand the problem, and formulate the context of the problem into mathematical models. On the one hand, understanding the problem in a contextual problem is fundamental before solving the problem. In other words, students have not been able to understand and formulate problems in everyday life into mathematical models. "

In line with Windari's findings, et al (2014: 25-26) stated that "based on the results of tests that obtain students' mathematical problem-solving ability are still low. When interviewed with one of the mathematics 
teachers, information was obtained that training in problem-solving was still rarely obtained, right?

The explanation above shows how important problem-solving ability are in the process of teaching and learning mathematics. The question is whether the learning objectives of mathematics have been achieved? What should be the management of mathematics learning in schools so that the expected goals are achieved? Teachers must strive for learning by applying learning models that can provide opportunities and encourage students to practice problem-solving skills. But it is unfortunate, the teacher has not packaged learning optimally, then the learning environment is less conducive, so learning is not fun, and the lack of student participation in learning activities.

One learning that requires student activity and uses problems or experiences of students in daily life towards mathematics is learning Model Eliciting Activities (MEAs). This is reinforced by Suningsih's opinion (2015: 32) states that: "Through MEAs learning, students can utilize the problems that exist in daily life to build student learning concepts and construct new knowledge and adjust it to the old knowledge of students because of construction. mathematical models or solve problems, students need information in the form of old knowledge as well as data and images ".

In line with the opinion of Akhmad \& Masriyah (2014: 98) that "Approach Model Eliciting Activities (MEAs) is a learning approach that focuses on student activities to obtain or obtain a solution of a real problem obtained through the process of applying mathematical procedures to form a mathematical model".

In line with the opinion of Chamberlin and Moon (2008: 4) that "Model Eliciting Activities (MEAs) is a learning model that focuses on student activities to get or get a solution to the problems obtained through the process of applying mathematical procedures to form a mathematical model. The main purpose of this learning is that students can apply mathematical procedures to form a mathematical model. By learning Model Eliciting Activities (MEAs), student learning is more meaningful because it can connect what it learns with concepts that it already knows ".

Based on the description above, the Eliciting Activities Model (MEAs) is a learning model that supports student activities in bringing in, getting or obtaining solutions to problems that get through student thought processes to create a mathematical model as a solution. In addition, Eliciting Activities Model (MEAs) is based on real-life situations of students, working in small groups, and presents a mathematical model as a solution, as well as interpreting the problem-solving solution back to the real world.

Besides the learning model, one of the factors that are very interesting to be investigated is gender. In learning mathematics, a similar mathematical problem such as getting it to several individuals will get a different response/response in solving it. The difference in how to solve it is because each individual has uniqueness in himself. Another thing that might cause differences in each individual in responding to a problem is the existence of gender differences (Susilowati, 2016: 137).

Then the results Wardani (2014: 99) found that "students male and students of women have differences in the stage of solving the problem in question, differences emerged on the stage of implementing the plan and check back. As for the stage of understanding the problem and formulating a plan, there is no significant difference ".

Furthermore, the results of Anggraeni and Herdiman's research (2018: 19) state that "the mathematical problem-solving ability of female subjects is better than male subjects. This is reflected in the results of the acquisition of the average correct score of each indicator which shows that female subjects have an average higher than male subjects. This is influenced by the better time management of female subjects compared to male subjects, wherein doing the settlement, the female subject tends to pass through the first step of the solution or the problem which is considered difficult to further work on other problems first. However, for other things there is no fundamental difference between female and male subjects in solving mathematical problem-solving in the form of contextual matter proposed circle material ".

Based on the results of the above research it can be concluded that gender differences have a part to influence someone in solving mathematical problems, but these differences are not consistent. In this study, gender differences only distinguish sex between men with women in hooks right with the ability of students' mathematical problem-solving. For this reason, by applying the eliciting activities model, the ability to solve mathematical problems of male and female students is expected to be better than before.

\section{Method}

This research is categorized into quasi-experimental research (quasi-experiment), conducted in SMP IT Nurul Fadhilah Deli Serdang in the Academic Year 2019/2020 there is the number of students 43 people were homogeneous is class VIII (the experimental class and control class).

The research design can be seen in Table 1 . 
Table 1. Research design

\begin{tabular}{|c|c|c|}
\hline Group & Treatment & Posttes \\
\hline Experiment & $\mathrm{X}$ & $\mathrm{O}$ \\
\hline control & - & $\mathrm{O}$ \\
\hline
\end{tabular}

Information:

$\mathrm{X}$ : Treatment of learning with eliciting activities model

O: Posttest experimental group and control group

The interrelations between a free, bound and control variable are presented in the Weiner table as follows:

Table 2. Weiner Table about the Correlations between Independent, Bound and Control Variables

\begin{tabular}{|l|l|l|l|}
\hline \multicolumn{2}{|l|}{ Measured Ability } & \multicolumn{2}{c|}{ Learning model } \\
\hline \multicolumn{2}{|l|}{ Mathematical Solving Ability ( PM ) } & Model Eliciting Activities (A) & Direct learning (B) \\
\hline \multirow{2}{*}{ Student Gender } & Male ( L ) & PMAL & PMBL \\
\cline { 2 - 4 } & Female ( P ) & PMAP & PMBP \\
\hline Whole & PMA & PMB \\
\hline
\end{tabular}
ability.

Data collection techniques in this study used tests to measure students' mathematical problem-solving

Data processing in hypothesis testing begins with testing the necessary statistical prerequisites, namely the normality test and the homogeneity variance test. Subsequently an analysis of varians (ANOVA). All statistical calculations use the help of SPSS 2.0 computer programs and Microsoft Excel programs.

\section{Results And Discussion}

To answer the research questions raised in the introduction, analysis, and interpretation of the research data is needed. The analysis in question is to determine differences in students' mathematical problem-solving ability in the material system of linear equations of two variables that obtain learning with different models. The experimental class gained learning by model eliciting activities, while the control class obtained direct learning . Next will be seen the interaction between learning (model elciting activities and direct learning ) with the gender of students ( male and female ) to the students' mathematical problem solving ability .

Ability test problem solving mathematical done one time that the final assay (posttest). The final test was followed by 21 students for the experimental class and 22 students for the control class so that in the analysis of data the subject of this study were 43 people who took the final test (posttest).

\subsection{Description of Students' Mathematical Problem Solving Ability}

The problem solving skills that are given the learning model of eliciting activities. The following results of the calculation of the average and standard deviation of the problem-solving ability both from the experimental class and the control class as shown in table 3:

Table 3 Data Description of Students Mathematical

Problem Solving Ability

\begin{tabular}{|c|c|c|}
\hline \multirow{2}{*}{ Statistics } & \multicolumn{2}{|c|}{ Learning } \\
\cline { 2 - 3 } & MEAs & Direct Learning \\
\hline $\mathrm{N}$ & 21 & 22 \\
\hline Average & 81 & 70 \\
\hline Standard Deviation & 7,61 & 8.92 \\
\hline
\end{tabular}

In table 3 above that the average mathematical problem solving ability of students who are given learning Model Eliciting Activities (MEAs) is 81, while the average value of mathematical problem solving ability of students who are given direct learning is 70 . So the average mathematical problem solving ability experimental class students are better than the average control class mathematical problem solving ability of students.

Based on the posttest data obtained the lowest score $\left(x_{\min }\right)$, highest score $\left(x_{\text {maks }}\right)$, average score $(\bar{X})$ and standard deviation $(S D)$ for experimental class and the control class as in Table 4 below: 


Table 4 Average Mathematical Problem Solving Ability of the
Experimental Class and the Gender Based Balance Class .
\begin{tabular}{|c|c|c|c|c|c|}
\hline \multirow{2}{*}{ Learning } & \multirow{2}{*}{ Gender } & \multicolumn{5}{|c|}{ Problem solving skill } \\
\cline { 3 - 6 } & & Mean & SD & Min & Max \\
\hline \multirow{2}{*}{ Experiment } & LK & 77 & 6.0 & 70 & 85 \\
\cline { 2 - 6 } & Homework & 88 & 4.41 & 83 & 98 \\
\hline Control & LK & 66 & 8.54 & 50 & 78 \\
\hline & Homework & 74 & 7.17 & 60 & 85 \\
\hline
\end{tabular}

At $\mathrm{T}$ able 4 shows that the mean and standard deviation of the problem solving mathematical former class perimen with Gender student male of 77 and 6.0, and women at 88 and 4.41. Meanwhile, for the ability of solving the problem class k ontrol with Gender male students mean and standard deviation of 66 and 8.54 and women of 74 and 7.17 .

\subsection{Data Normality Test Troubleshooting Ability}

The results of a summary calculation of the normality of posttest mathematical problem solving ability are presented in Table 5 below:

Table 5 Normality Test Mathematica
Problem Solving Ability.
\begin{tabular}{|l||c||c||c||}
\hline Class & N & D $_{0}$ & D table $^{-1}$ \\
\hline \hline Experiment & 21 & .146 & 0.290 \\
\hline Control & 22 & .147 & .297 \\
\hline
\end{tabular}

It can be seen from Table 5 above that the successive values of $\mathrm{D}_{0}$ are 0,146 and 0,147 for the experimental class and the control class is smaller than the $\mathrm{D}$ table so that it can be concluded that the experimental class and control class are derived from the normal distributed population . In addition, normality calculations are also carried out using the SPSS 20 program. The calculation results are as follows:

Table 6 Test Results for Normality Test for Troubleshooting

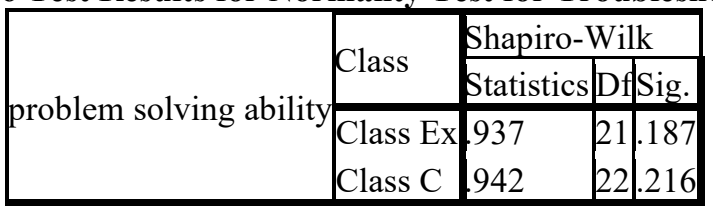

Based on $\mathrm{T}$ abel 6 above obtained value of significance for data problem solving mathematical students the experimental class and class ontrol respectively 0,187dan 0,20 6. Value siginifikansi these two classes is greater than the value of 0.05 . So we can say that the data experimental class and the control class is derived from a population that is normally distributed.

\subsection{Homogeneity Test Data Problem Solving Capability}

Homogeneity test calculation results can be seen in Table 7 below:

Table 7 Test the Homogeneity of Variance Ability to Solve Problems

\begin{tabular}{|c|c|c|c|}
\hline Class & Variance $\left(\mathbf{s}^{\mathbf{2}}\right)$ & $\mathbf{F}$ count & $\mathbf{F}_{\text {table }}$ \\
\hline Experiment & 58,885 & \multirow{2}{*}{$\mathbf{7 4}$} & $\mathbf{2 . 0 6}$ \\
\hline Control & 79.87 & & \\
\hline
\end{tabular}

Based on Table 7 above, it is obtained that the calculated $\mathrm{F}$ value $<\mathrm{F}$ table is $0.74<2.06$, then the sample comes from a homogeneous data group variance. Mean while the results of homogeneity calculations for the posttest of the problem solving ability in the experimental class and in the control class using SPSS 21 are briefly described as follows:

\section{Table 8 Data Homogeneity Test Results Problem Solving Capability Test of Homogeneity of Variances problem solving skill

\begin{tabular}{|c|c|c|c|}
\hline Levene Statistics & df1 & df2 & Sig. \\
\hline .152 & 1 & 41 & 699 \\
\hline
\end{tabular}

Based on Table 8 gives significance value (sig.) $=0,699$ is greater than 0.05 , then $\mathrm{H}_{0}$ is accepted. Thus both samples come from populations that have homogeneous variance. So based on the hypothesis test that has been done, it is stated that the sample group of the study came from populations with normal distribution and homogeneous variance.

Furthermore, need to be tested significan differences in the ability of solving mathematical in learning the model eliciting activities and learning directly analyzed with statistical test analysis of varians. Two-way 
ANOVA is used after fulfilling the analysis prerequisite test that is normality test and homogenity test. The twoway ANOVA test results are presented in Table 9 below.

\subsection{Statistical Analyze AN A VA Two Paths}

The summary results are presented in the following Table 9:

Table 9 ANAVA Test of Problem Solving Capability

Tests of Between-Subjects Effects

Dependent Variable: problem_solving ability

\begin{tabular}{|l|l|l|l|l|l|}
\hline Source & Type III Sum of Squares & df & Mean Square & F & Sig. \\
\hline Corrected Model & $2470,959^{a}$ & 3 & 823,653 & 17,091 & .000 \\
Intercept & 243424,418 & 1 & 243424,418 & 5051,090 & .000 \\
Gender & 968,212 & 1 & 968,212 & 20,091 & .000 \\
Learning & 1679,446 & 1 & 1679,446 & 34,849 & .000 \\
Gender * Learning & 16,398 & 1 & 16,398 & .340 & .563 \\
Error & 1879,506 & 39 & 48,192 & & \\
Total & 249990,000 & 43 & & & \\
Corrected Total & 4350,465 & 42 & & & \\
\hline
\end{tabular}

\section{1) Learning Factors}

a. $\mathrm{R}$ Squared $=.568($ Adjusted $\mathrm{R}$ Squared $=.535)$

The test is based on the hypothesis are:

$\mathrm{H}$ o : (There is no difference in the ability to solve problems between students who receive learning model eliciting activities and students who receive direct learning )

$\mathrm{H}_{\mathrm{a}}$ : ( terdapa $\mathrm{t}$ difference between the problem solving ability of students acquire the learning model of eliciting activities with students who acquire learning directly )

\section{Statistical Hypothesis 1 :}

$$
\mathrm{H}_{0}: \mu_{1}=\mu_{2}
$$

$\mathrm{H}_{\mathrm{a}}: \mu_{1} \neq \mu_{2}$

Based on the Two-Way ANOVA test results in Table 9 it can be seen that the calculated $\mathrm{F}$ value is 31.54 and the significance value $\alpha=0.000$. So that the level of significant value learning model eliciting activities with students who obtain direct learning is smaller than $\alpha=0.05$ then $\mathrm{H}_{0}$ is rejected and $\mathrm{H}_{\text {a }}$ accepted . So it can be concluded that there is no difference in the ability of problem solving between students who receive learning model eliciting activities and students who obtain direct learning are rejected. So there is a difference in the ability of problem solving between students who obtain learning eliciting model activities and students who receive direct learning are accepted.

\section{2) The Interaction Between Learning and Gender Students Against the Ability to Solve Mathematical} Problems .

The hypothesis proposed for the ANAVA test is formulated as follows:

Ho: (There is no interaction between learning models and Gender on students' mathematical problem solving ability )

$\mathrm{H}_{\mathrm{a}}$ : ( $\mathrm{T}$ erdapat interaction between learning models and gender on students' mathematical problem solving ability )

\section{Statistical Hypothesis 2 :}

$\mathrm{H}_{0}:(\alpha \beta) \mathrm{ij}=0$

$\mathrm{H}_{\mathrm{a}}:(\alpha \beta) \mathrm{ij} \neq 0 ; \mathrm{i}=1,2 ; \mathrm{j}=1,2$

From Table 9 was obtained that $\mathrm{F}$ count was 3.97 and the value of significance (sig.) For the category of gender is 0.563 greater than $\alpha=0.05$, which means that $\mathrm{H}_{0}$ is accepted and rejected $\mathrm{H}_{\mathrm{a}}$, meaning there is no interaction between learning models and Gender for students' mathematical problem solving ability can be accepted. So there is a joint influence between learning and Gender on students' mathematical problem solving ability rejected. This means that the difference between the average scores of students' mathematical problem solving ability in the male and female gender categories respectively taught by learning aliciting activitis models and direct learning did not differ significantly. More clearly, there is no interaction between learning models and Gender on students' mathematical problem solving ability, presented in Figure 1 : 


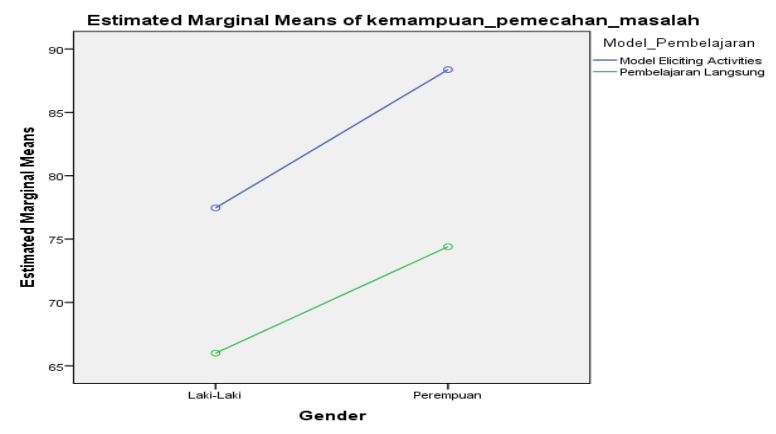

Figure 1 Interaction between Learning Model and Gender Against Students' Mathematical Problem Solving Ability

\section{Conclusion}

Based on the results and discussion of the study, the following conclusions are obtained:

1. There are differences in the ability of solving mathematical among students who received learning model eliciting Activitis and direct learning .

2. There is not interaction between models of learning (Model eliciting Activitis and direct learning ) and Gender (Male and Female) on the ability of problem solving matemat is students. It is understood that the interaction between the model of learning (Model eliciting Activitis and direct learning ) and gender (male and female) did not have an impact both together are significant to the ability of problem solving mathematic students.

\section{References}

Akhmad, AGP \& Masriyah. (2014). The Effectiveness of Mathematics Learning Using the Model-Eliciting Activities (Meas) Approach in the Equation Material and Linear Inequality of One Variable in Class VII-A of SMP Negeri 1 Lamongan. MATHE dunesa: Scientific Journal of Mathematics Education, 3 (2): 97-102.

Anggraeni, R \& Herdiman, I. (2018). Ability to Solve Mathematical Problems of Junior High School Students in Circle Material in the Form of Contextual Problems in Terms of Gender. Journal of Numeracy, 5 (1), p. 19-28.

Chamberlin, SA, \& Moon, SM (2008). How Does The Problem Based Learning Approach Compare to The Model-Eliciting Activity Approach in Mathematics ?. International Journal for Mathematics Teaching and learning, (Online), ( http://www.cimt.plymouth.ac.uk/journal/chamberlin .pdf, accessed 25 February 2019).

Jainuri, M., \& Riyadi, S. (2017). Synectic Model Experimentation of Students' Mathematical Problem-Solving Ability and Self-Efficacy . Edumatica, 07 (02): 51-60.

National Council of Teachers of Mathematics (NCTM). (2000). Principles and Standards for School Mathematics . Reston VA: NCTM.

Suningsih, A. (2015). " Straight Line Learning with MEAs and TAI Judging from the Cognitive Style ". Journal of e-DuMath, 1 (1): 30-42.

Susilowati, J.PA. (2016). Reasoning Profile of Junior High School Students in Mathematical Problem Solving in Terms of Gender Differences. Journal of Mathematics Learning Review . 1 (2): 132-148

Wardani, AK (2014). Ability to Solve Problems Based on Sex Differences. Journal of Mathematics Education STKIP PGRI Sidoarjo . 2 (1): 99-108.

Windari, F., Dwina, F and Suherman. (2014). Improving the Mathematical Problem Solving Ability of Class VIII Students in Junior High School 8 Padang Academic Year 2013/2014 Using Inquiry Learning Strategies. Journal of Mathematics Education , 3 (2): 25-28. 